\title{
Vincze Teréz
}

\section{Nôi érzékek - Rendezónók nôalakjainak fenomenológiai olvasata}

\begin{abstract}
Absztrakt
A dolgozat a fenomenológiai filmelmélet, azon belül is elsôsorban Vivian Sobchack elgondolásaiból kiindulva nôi alkotók nôi főszereplôs alkotásainak fenomenológiai szempontú olvasására tesz kísérletet. A Merleau-Ponty egzisztenciális fenomenológiáját a filmelmélet számára továbbgondoló Sobchack a testiesült filmbefogadást, a film és a nézô teste közötti értelemképző kapcsolatot vizsgálta. Olyan filmelemzést javasolt, mely a szokásos, a jelentésstruktúrákra koncentráló elemzô beszédtôl elmozdul a tapasztalat „sûrú és radikális leírása” felé. A szöveg, miután röviden összefoglalja a fenomenológia filmelméletben elfoglalt helyének kérdését és a feminista szempont és a fenomenológia összekapcsolhatóságának problémáját, a Sobchack által javasolt sûrü leírásra tesz kísérletet két, a közelmúltban készült film kapcsán (Kocsis Ágnes: Éden, 2020; Céline Sciamma: Portré a lángoló fiatal lányról, 2019). Az elemzések vizsgálják a nézôknek a haptikus képek által elóidézett testi megszólítottságát; a szenzuális és a formális-strukturális filmszerkesztés egymáshoz viszonyított dinamikáját; a test és tér viszonyát a diegézisben és a nézókhöz füződő kapcsolatban; a térbeli trópusok kidolgozását; a nôk egymás közötti nézésének szerkezetét. Mindezek alapján, az általánosítás igénye nélkül, a sûrû́ leírás segítségével a szöveg megkísérli megragadni e filmek sajátosan nôi szenzibilitását.
\end{abstract}

\section{Szerzó}

Vincze Teréz filmkritikus, egyetemi oktató. 2000-ben az ELTE magyar nyelv és irodalom, valamint esztétika szakán diplomázott, 2009-ben az ELTE BTK Filozófia Doktori Iskolájának esztétika doktori programján védte meg doktori $(\mathrm{PhD})$ értekezését. 2004-tôl tanársegédként, 2010tôl adjunktusként tanít az ELTE Filmtudomány Tanszékén. 1999 óta a Metropolis filmelméleti és filmtörténeti folyóirat szerkesztôje, 2003 és 2009 között föszerkesztôje volt. Elsố könyve Szerzö a tükörben: Szerzôiség és önreflexió a filmmüvészetben címmel jelent meg 2013-ban. Filmtudományi publikációi angol, német, olasz, cseh, szlovák és koreai nyelven folyóiratokban és szerkesztett kötetekben jelentek meg. 
Jelenlegi kutatási területei: a test és a testi érzékek szerepe a filmben, feminizmus és genderreprezentációk a vizuális kultúrában, szerzőiség a kelet-ázsiai filmmúvészetben.

https://doi.org/10.31176/apertura.2021.16.2.9 


\title{
Vincze Teréz
}

\section{Nôi érzékek - Rendezónók nôalakjainak fenomenológiai olvasata}

\author{
A fenomenológiai vagy egzisztenciális filozófia legnagyobb részét teszi ki az a \\ rácsodálkozás, hogy mennyire szorosan tartozik az én a világhoz
}

(Maurice Merleau-Ponty) ${ }^{[1]}$

Írásom egyik ihletôje egy képsor, amely a filmelméletben az 1990-es évek elejétôl felerôsödô fenomenológiai irányzat, valamint a női nézôpont és női filmkészítés találkozásának emblematikus momentumává vált. Jane Campion A zongoralecke (The Piano, 1993) címú filmjének nyitó képsoráról van szó, melyben elôször szinte felismerhetetlen, mozgó fényfoltokat látunk, majd lassanként kiderül, hogy egy nô szubjektívje ez, s az arca elé tett kezének ujjai közti réseken átszưrôdő fényt látjuk. E jelenet érzékletes és megvilágító erejú fenomenológiai olvasatát Vivian Sobchack fogalmazta meg Carnal Thoughts: Embodiment and moving image culture ${ }^{[2]}$ címú könyvének egyik tanulmányában. A szövegben Sobchack a film nyitójelenete kapcsán a saját testi élményérôl ír: „Campion filmje mélyen megérintett, felkavarta érzékeimet, sốt egész testem érzékelését". ${ }^{[3]}$ A film elsô két snittje alatt átélt érzéki és értelemképzố [sensual és sense-making] ${ }^{[4]}$ élményeinek vizsgálatán keresztül szemlélteti, hogyan múködik a testi befogadás, melynek során a néző ujjai már elôbb „tudják”, hogy mi az, amit „lát”.

Campion filmjének képsora és Sobchack ezzel kapcsolatos gondolatmenete a filmrôl való fenomenológiai alapozású gondolkodás esszenciáját ragadják meg, amihez gyakran visszatérek, amikor kétségeim támadnak a fenomenológia filmtudományi alkalmazhatóságával kapcsolatban. E képsor múködésének, hatásmechanizmusainak érzékeléséhez (direkt nem használom a megértés szót) valóban szükség van a szokásos, a jelentésstruktúrákra koncentráló beszédtôl elmozdulni „a tapasztalat sûrú és radikális leírása” [5] felé, mely a szoros önmegfigyelésen keresztül emlékeztet, hogy „egy film sincs, amit kizárólag a szemünk által élünk át”. [6]

E kanonikusnak számító epizódot és fenomenológiai interpretációját a tanulmány írásakor két kortárs nôi rendezố utóbbi idôben készült, nôi hôsöket középpontba állító filmjének egy-egy jelenete idézte fel bennem. Jelen szöveg közvetlenebb „érzéki és értelemképzô” élménymagja e két rövid képsor, melyek ismét nyilvánvalóvá tették számomra, hogy a fenomenológiai megközelítés bizonyos esetekben valóban nélkülözhetetlen a filmélmény, a mozgóképi hatás minél teljesebb leírásához.

Az egyik jelenet Kocsis Ágnes 2020-ban Éden címmel bemutatott filmjének egy epizódja. A film 
fôhoôse, Éva középkorú nő, aki úgy tûnik, a modern világ szinte minden jelenségére allergiás: a tisztítószerektôl a mobiltelefonok adótornyai által kibocsátott sugárzásig, a festékektôl az elektromos berendezésekig. Betegségéból kifolyólag egy teljesen steril és rideg lakásba zárva él, ahonnan csak szkafanderbe öltözve léphet ki, akkor is fóként csak azért, hogy eljusson a kórházba, ahol kísérleteket végeznek rajta. A filmben Éva vizsgálatára kirendelnek egy pszichiátert, hogy állapítsa meg, a tünetei pszichológiai eredetúek, vagy külsô behatás okozza-e ôket. A vizsgálat legfontosabb közvetlen következménye, hogy a hosszú ideje emberi kapcsolatoktól izoláltan élő nô életében megjelenik egy idegen (férfi), akivel rendszeresen idốt tölt, beszélget. Az ennek nyomán kezdôdő átalakulás egyik fontos kísérôje Éva mobilitásának változása. Egyre többet mozdul ki a lakásból, és a lassan terápiává alakuló vizsgálat végsô céljává pedig az válik, hogy Éva kiszabadulhasson a szkafanderból, és visszatérhessen a természetbe, a szabad levegóre.

A kiemelt jelenet a bezártság és elszigeteltség, valamint a fizikai és érzelmi értelemben vett kimozdulás közötti folyamat egyik kulcsmomentuma egy olyan pillanat, mely a film érzelmi konfliktusát egy jellegzetesen érzéki gesztusba süríti, aminek a leírására leghatékonyabbnak az egzisztenciális fenomenológia látszik. A jelenetben Éva és András (a pszichiáter) egy zongorakoncerten vannak. Éva hatalmas szkafanderében ül a nézôtéren. A zongorán felcsendülő Schubert-darab már önmagában jelentôs érzelmi erôvel csap le a befogadóra a koncertterem faborítású, melegfényưre világított, óriási, barlangszerú terében az egyébként rideg fémbútorok között csikorgó, kongó hangok és a téli látképek után, amelyek különben Éva életterét jellemzik. Az ormótlan szkafanderben, mindentôl és mindenkitôl fizikailag elszigetelten ülő Éva is a zene hatása alá kerül. Arcát látjuk a szkafander üvegén keresztül, érzelmek tolulnak fel benne, szeméból könny csordul. Önkéntelenül az arca (a könnycsepp) felé nyúl, azonban kesztyús keze az arcát fedô sisak kemény borításának koccan. Ez a pillanat, ahogy a sisaknak koppanó kéz mozdulatában hirtelen „tapinthatóvá“ válik a rendkívüli elszigeteltség, ahogy Éva még a saját testétôl, saját érzékelô és érzố húsától is el van zárva, különös erôvel hat. Ez a gesztus befogadóként érzelmi bevonódásomat új szintre emeli, s ezt a saját testemben megélt és felidézett meggátoltság érzésén keresztül éri el. Schubert zenéje már felépíti az érzelmi hatás intenzitását, azonban az önmagától való elszigeteltség gesztusa e mozdulatban nagy erôvel kapcsolja Éva helyzetének tragikumát a pillanat érzelmi töltöttségéhez. E pillanatot nagyon határozottan a saját ujjaimmal is „látom“, jelentését testben megéltként képzem meg. Az értelem efféle megképzésérôl beszél MerleauPonty fenomenológiája. „A test filozófiailag kitüntetett helyzete abban a tételben foglalható össze, hogy a test nem egyszerúen a tapasztalás közege, hanem egyszersmind az eredeti értelemképződés szerve is. Más szóval a test nem semleges összetevője a tapasztalásnak, hanem sajátos és másra vissza nem vezethetô forrása az értelem létrejöttének." [7] 
A másik hasonlóan intenzív élményem Céline Sciamma Portré a lángoló fiatal lányról (Portrait de la jeune fille en feu, 2019) címú filmjéhez kapcsolódik. A film záróképérôl van szó - a két és fél perces beállításban a film egyik fôhoosét látjuk, Héloise-t, amint egy színházi páholyban ül magányosan, másoktól elkülönülten és mély érzelmek öntik el, miközben Vivaldi Négy évszak címú múvét játssza a láthatatlan zenekar.

Az intenzív hosszú beállítás ereje nagyrészt abból az energiából származik, amely azáltal jön létre, ahogy az erôteljes érzelmek a szó szoros értelmében mozgásban tartják a zokogás kitörése ellen küzdô, szinte ziháló testet: az érzelmek testiesülésének szemtanúi vagyunk. Mindez a test túlcsorduló láthatóságát eredményezi, a látható létbe ágyazottság felfokozott materialitása játszik fontos szerepet e hatásmechanizmusban. Ahogy Sobchack fogalmaz: „Amikor a moziban ülünk és észleljük a filmet mint valami érzékit, értelemképzốt, mi (és a film elôttünk) egy világba, egy látható létbe ágyazódik. A tapasztalat ugyanannyira intenzív, mint amennyire ismerôs, és áthatja az a mód, ahogyan a jelentôség és a jelölés aktusa közvetlenül érezhetô, érzékileg hozzáférhetô a nézô számára." [8]

A test látványának intenzív hatása egyáltalán nem kézenfekvô és magától értetôdô a képekkel olyannyira elárasztott kortárs vizuális kultúrában. Sobchack Carnal Thoughts címú könyvében így fogalmaz: „Amikor azt mondjuk, hogy manapság elvesztettük a kapcsolatot a testünkkel, az nem azt jelenti, hogy szem elôl tévesztettük. Valójában úgy tûnik, fordított arányosság áll fenn aközött, hogy mennyire látjuk, és hogy mennyire érezzük a testünket: minél inkább tudatában vagyunk önmagunknak olyan kulturális termékek, szimbolikus töredékek és elóállított dolgokként, mint amelyeket képeken és képekként látunk, úgy tûnik, annál kevésbé érzékeljük az azokat alátámasztó korporeális létezés szándékolt összetettségét és gazdagságát." ${ }^{[9]}$ Ezért is lehet olyannyira erôteljes hatása a múalkotásnak, amikor a korporeális létezés eme gazdagságát képes megidézni a befogadó testében - saját tapasztalatom szerint erre képes Sciamma filmjének záró képe is.

Ez a két jelenet és összekapcsolódásuk $A$ zongoralecke ikonikus kezdôképeivel késztetett arra, hogy Vivian Sobchack nyomán e nôi filmkészítók nőfiguráinak ábrázolása kapcsán a fenomenológiai megközelítés lehetôségeirôl gondolkodjak. Mindezzel két fontos probléma adódik, melyek egyrészt a fenomenológia és a filmtudomány viszonyát, másrészt a fenomenológia és a női perspektíva összekapcsolásának lehetôségét érintik.

A filmelméleti gondolkodásban elfoglalt helyzetének szempontjából okoz némi ellentmondást, hogy Sobchack saját fenomenológiai vállalkozását, vagyis hogy „leírja és számba vegye a filmi jelölésnek és jelentôségnek mint testet öltött és jelentésteli egzisztenciális tevékenységnek az eredetét és helyét a látás tapasztalatában", nem teoretikus, hanem empirikus tevékenységként fogja fel, mely jellemzóen a látás tapasztalatának, a „világba merített megélt testnek” [enworlded lived body] a leírásából áll. ${ }^{[10]}$ Márpedig a filmtudományban ezt megelôzôen regnáló elképzelések kifejezetten az absztraháló, elvonatkoztató tevékenységet hangsúlyozták. Másfelól azonban bizonyos filmelméleti irányzatoknak a fenomenológiával való összevetésben kidomborodó hiányosságaira Dudley Andrew már egy 1978-as írásában felhívta a figyelmet. ${ }^{[1]}$ A szövegben 
sorra veszi a szórványosan felbukkanó fenomenológiai jellegú kezdeményezéseket a filmelméletben, és különösen a strukturalista/szemiotikai iskolával szembeállítva mutat rá elôbbi előnyeire, olyan tulajdonságaira, melyekkel utóbbiak hiányosságait pótolni lehetne: „a strukturalizmus és az intézményes filmelmélet általában alkalmatlanná vált arra, hogy a jelölés »túloldalával« foglalkozzék, vagyis a megalkotottság felismerését megelóző (preformulatív) jelenségekkel, ahol az érzetadatok jelentéstelivé állnak össze, vagy a felismerést követô (posztformulatív) jelenségekkel, ahol az így kialakult jelentés megtapasztalható. [...] a film formális kódrendszereinek osztályozása, bár szükséges feladat, nem helyettesítheti a filmvásznon megszületó jelentés sajátos tapasztalatának és a fontos filmek keltette élmények egyedi minôségének a leírását." [12]

Ebben a vonatkozásban teoretikusi önmegfigyelésemet is tanulságosnak tartom, amennyiben alapvetô vonzalmaimat tekintve mindig is a strukturalista és formalista gondolatrendszereket tartottam különösen izgalmas elemzô, feltáró eszközöknek. Az utóbbi két évtized filmtermése azonban egyre inkább felerôsítette bennem az igényt a fenomenológiai megközelítés lehetôségeinek kiaknázására az interpretációban. A kortárs mozgóképkultúra számos fejleménye mutat abba az irányba, hogy élményeinket az érzéki sokféleség szinesztetikus kontextusában „cinesztéziai szubjektumként” [13] ismerjük fel. Ahogy Sobchack fogalmaz: „Cinesztéziai szubjektumként tehát olyan testiesült intelligenciával rendelkezünk, amely szemünknek a konkrét nézést messze meghaladó kapacitást, a filmnek a konkrét látványt messze meghaladó tartalmat, a nyelvnek pedig sajátos karnális eredetét és határait felfedô, reflektív tudást ad.” [14]

A második probléma pedig, hogy feltehetô-e érdemben olyan kérdés fenomenológiai nézôpontból, melynek megválaszolásában szerepet játszik a gender-szempont. Lehetôséget ad-e a fenomenológia gender-specifikus megfigyelésekre? Mit jelent fenomenológiai szempontból a nói perspektíva, megragadható-e a nôiség fenomenológiailag? Összekapcsolható-e, és ha igen, miként a fenomenológiai a feminista gondolatmenettel?

Meglepő módon a fenomenológia és a feminista kritika összekapcsolásának történetét és lehetôségeit összegző 2017-es könyvében Kate Ince úgy nyilatkozik, hogy az ô munkája elôtt még egyetlen tanulmány sem foglalkozott a film kapcsán érdemben a „megtestesült nôi szubjektivitás” vizsgálatával. ${ }^{[15]}$ Ugyanakkor rámutat, hogy Gaylyn Studlar egy 1990-es tanulmánya ${ }^{[16]}$, majd pedig Sobchack 1992-es könyve ${ }^{[17]}$ kezdeményezte elôször a testet öltött tapasztalat (embodied experience) koncepciójának bevezetését a filmtudományba, ami Ince szerint egyben a feminista filmelmélet és a filmfilozófia elsố találkozásának is tekinthetô. ${ }^{[18]}$ Sobchack könyvében elég óvatosan fogalmaz feminizmus és fenomenológia lehetséges összekapcsolódásáról: célja MerleauPonty egzisztenciális fenomenológiájának „megélt test” (lived body) elképzelését gyakorlati eszközként felhasználni a filmi látvány egzisztencialista leírására; a projekt nem kifejezetten feminista, de egy olyan nó írja, aki elégedetlen a marxista és pszichoanalitikus elméletek adta lehetôségekkel, mivel azok szerinte korlátozták és zátonyra futtatták a feminista filmelméletet. ${ }^{19]}$ A feminista filmelmélet „megjavítására” azonban nem feltétlenül kézenfekvő eszköz a 
fenomenológia. A feminizmus definíció szerint - amennyiben alaptörekvése végeredményben mindig politikai, hiszen a társadalomban fennálló egyenlôtlen hatalmi viszonyok kritikája és megváltoztatásának szándéka mozgatja - ellentétesnek túnik a fenomenológia akár transzcendentális, akár egzisztenciális felfogásával, melyek konkrét politikai vonatkozása sokkal kevésbé ragadható meg (ha egyáltalán). Ince is megjegyzi, hogy Constance Penley egy 1989-es írásában ${ }^{[20]}$ már felvetette, hogy hasznos lenne összekötni a fenomenológiát a filmelmélettel, azonban éppen a politikai kritikában való hatékonyság kapcsán voltak kétségei. [21]

Mindazonáltal a feminista filmelméletben a nôi test mindig fontos téma volt, de a második hullám klasszikus teoretikusai ezt inkább egyfajta kényszerként élték meg, amit magának a patriarchális diszkurzusnak a nôi testre fókuszáltsága kényszerített ki, s emiatt nem feltétlenül társultak pozitív képzetek a témához. Ahogy Elena Del Rio fogalmaz: „Az 1970-es, 80-as évek feminista filmelméletére rányomta a bélyegét az esztétikai és vizuális élvezet forrásának tekintett nôi testtel szembeni mélységes gyanakvás.” ${ }^{[22]}$ Ez a gyanakvás pedig alapvetôen gátolta, hogy a feminista filmelmélet szövetségre lépjen a Merleau-Ponty által megfogalmazott, fenomenológiai testkoncepcióval.

Kate Ince felhívja a figyelmet egy további problémára is, ami írásom szempontjából érdekes lehet: a nôi szerzôség (female authorship) sosem került a feminista elméletek fókuszába. ${ }^{[23]}$ Catherine Grant a szerzőiségnek a feminista elméletben elfoglalt pozícióját áttekintố szövegében úgy fogalmaz, hogy sok feminista teoretikus a szerzőiség (auteurism) koncepcióját azért vetette el, mert az a „férfi személyiség szexista kultuszán” alapult. ${ }^{[24]}$ Ez okoz némi nehézséget akkor, ha komolyan kívánom venni, hogy érdemes speciálisan nôi alkotók filmjeivel foglalkozni.

A fenomenológiai megközelítés és a feminizmus összekapcsolhatóságának nehézségei, valamint a női szerzôiség feminista koncepciójának kidolgozatlansága ellenére írásom további részében mégis érdemesnek tartom kifejezetten nôi alkotók nôalakjait fenomenológiai aspektusból vizsgálni. Ebben Sobchack mellett támaszkodom Kate Ince munkájára, mely az egyik elsô kísérlet a film kapcsán a megtestesült nôi szubjektivitás (embodied female subjectivity) kiterjedtebb vizsgálatára, aminek az érdekében áttekinti a megtestesültség koncepciója miként változtatja meg a nôi nézôség értelmezését. Ince is olyan filmpéldákat választ, melyekben nôi alkotók nôi fôszereplôket ábrázolnak, s arra tesz kísérletet e filmek elemzésekor, hogy ne csak a szereplő(k) helyzetére, testi és érzelmi tapasztalataira, interszubjektív találkozásaira koncentráljon, melyek filmbeli fejlődésükre, változásaikra vannak hatással, hanem „a nôi interszubjektivitásnak a rendezô és karakter, valamint a karakter és nézô között érzékelhetô dinamikájára” [25] is. Úgy fogalmaz, hogy ezek a filmek a nôi rendezố és a nôi karakter viszonyából adódóan mind hordozzák a nốk közötti „elsôdleges nézést” [primary look], mely megelôzi a nézôknek a filmre irányuló nézését. [26]

Sobchack gondolatát ${ }^{[27]}$ parafrazeálva úgy fogalmaznék tehát, hogy jelen szöveg nem kifejezetten feminista, de egy olyan nố írja, aki filmnézôi tapasztalatának rendre fontos, minôségi összetevőjeként ismeri fel e nők közötti „elsôdleges nézésnek” a tapasztalatát. Ugyanakkor a 
következő filmértelmezésekben megpróbálom feltérképezni, „a filmek milyen módon »érintenek « vagy »hatnak « meg bennünket testi értelemben; miként hoznak létre bennünk - még az elemzô tudatot megelózve - »karnális gondolatokat«". Vagyis komolyan veszem Sobchack megállapítását, miszerint „a filmélménynek nem csupán az én testem oldaláról, hanem az én testem miatt van jelentése." [28]

\section{Túlérzékenység: Éden (Kocsis Ágnes, 2020)}

Kocsis Ágnes filmjének strukturális érdekessége, hogy a formalista jellegú eltávolítás szigorú lehatároltsága és az erốteljes testi-érzéki hatáskeltés feszültségében születik meg a sajátosan fenomenológiai vonatkozású téma és történet - a test teljes elszigetelődése a világtól, a „megélt test" ellehetetlenülése - feldolgozása. A film egyszerre nagyon rideg és formalista abban az értelemben, hogy a korlátozott élettérben mozgó Éva betegsége által motivált kényszerú megtervezettséget és szisztematikus, steril kiüresítést a film egyik fontos esztétikai szervezőelvévé teszi. Az alapos kiszámítottság, a geometriai pontosság, a szigorú komponáltság a képalkotásban, a szereplők viselkedésében, a motívumok rendszerének kidolgozásában egyaránt szerepet kap. Ugyanakkor a kifejezésmód nagyon is zsigeri hatásokkal kelti életre a sokszor hideg, absztrakt világot a kongó, csikorgó, sziszegó hangokkal, melyeket például Éva lakásának steril fémbútorai, a levegốt tisztán tartó berendezések zajai képeznek.

A fôhhôs normális életből való kirekesztettségének érzését a fốcím elôtt megjelenô képek nemcsak azáltal teremtik meg, hogy Évát rögtön egy üvegkalitkába zárva látjuk, hanem a komponálás teremtette rideg és geometrikus minôség által is. A cím után azonban tipikus haptikus, a vizualitáson túli érzékeket is megszólító kép következik.

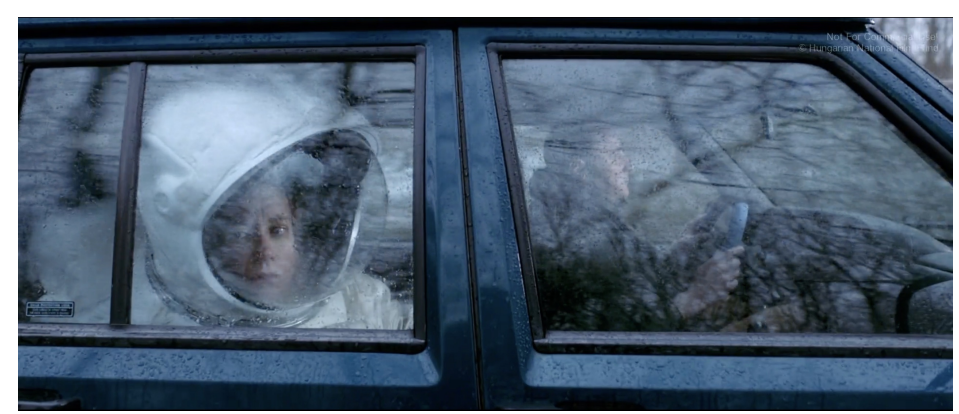

Kocsis Agnes: Éden (2020) 
Éva és testvére autóban utaznak hazafelé egy kórházi vizsgálat után. Éva szkafanderben ül az autóban, a kamera az autón kívülrôl rögzíti a jelenetet, így közénk és Éva arca közé kettôs, tükröződô felület kerül: a sisak és az autó üvege. Az autó ablakán lévô esốcseppek, valamint az ablak és sisak üvegén tükrözôdő útmenti fák különösen szaturált, gazdag textúrájú képet hoznak létre, melyben egyszerre fejeződik ki Éva sokszoros bezártsága és elszigeteltsége, ugyanakkor a látvány érzéki, haptikus minôségével a rendezô elkezdi felépíteni azt a struktúrát, melyben a film központi problémájának „érzékeléséhez” a nézô testi megszólítása is hozzátartozik.

A két fôszzereplô, Éva és András elsô találkozását is az érzékek haptikus játékba hozása jellemzi kettôjük viszonya azonnal az érintés és a szaglás érzékei mentén definiálódik. András a lakásban található, a sterilitás érdekében fémból készült bútorokat, tárgyakat elsô érkezése után megérinti, tapintással méri fel a fura környezetet. Majd elsô beszélgetésük is úgy kezdôdik, hogy az üdvözlésül kinyújtott kezének érintését a nô (elôvigyázatosságból) elutasítja, s a beszélgetés Éva megjegyzésével zárul, miszerint még meg kell szoknia a férfi illatát, mielôtt több idốt tudnának együtt tölteni.

Az extrém elzártság és magány kontextusában a testi, taktilis gesztusok szinte szükségszerúen különös hangsúlyra tesznek szert. Például az a jelenet, melyben Éva fehér krémbe mártott ujjával rajzol az éjszaka sötétjének vásznára az ablaküvegen, erôteljes taktilitásával ugyanolyan erôvel szól az érintés utáni vágyról, mint amennyire kifejezi, hogy allergiája miatt mennyire el van zárva a kreativitás megnyilvánításához szükséges anyagoktól, és ezáltal a kreativitás kifejezésétôl és megélésétôl.

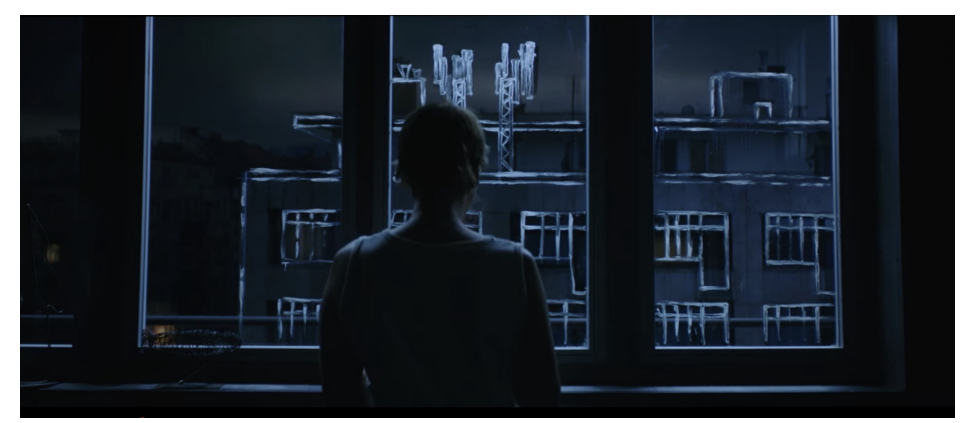

Kocsis Agnes: Éden (2020)

Beszédes Éva hobbiként múvelt tevékenysége, a drótokból hajtogatott szobrok és tárgyak készítése is, mely láthatóan nem mindig kellemes elfoglaltság, látjuk, amint a durva anyag felsérti a kezét.

E hangsúlyozottan haptikus világnak a megteremtésében a film alkotói különösen fontos szerepet ruháztak a hanghatásokra, a film anyagi világának a hangokon keresztüli megteremtésére a befogadóban. Az a beállítás, melyben Éva a fém konyhaasztalon ujjával végigtol egy üvegpoharat, nemcsak Tarkovszkij Sztalkerének (1979) utolsó jelenetét idézi meg, hanem az anyagiságot erôteljesen érzékeltetố hang létrehozza a nézố szinesztéziás kapcsolatát Éva tárgyi világának ridegségével. 


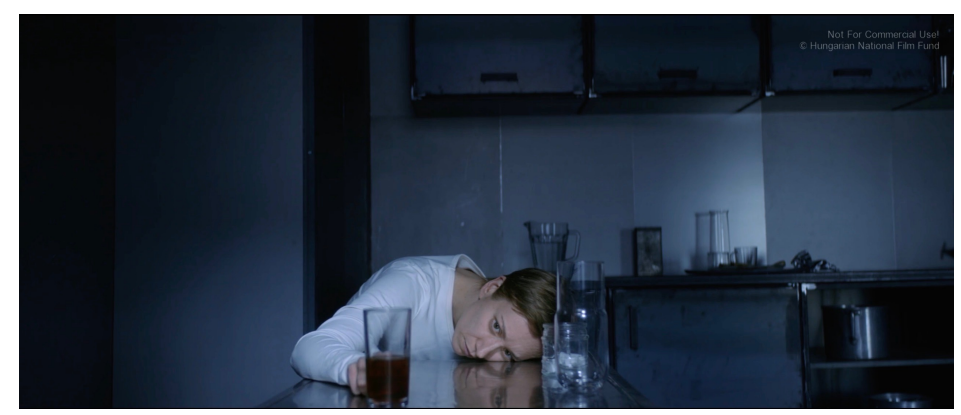

Kocsis Agnes: Éden (2020)

Az ilyen fajta jelentésalkotást próbálja megragadni Sobchack „cinesztéziai” szubjektum fogalmával: „Nevezzük a filmélmény szubverzív testét cinesztéziai szubjektumnak [cinesthetic subject]. (...) A cinesztéziai szubjektum szenzuális és intermodális tevékenységének köszönhetôen egyszerre van itt és ott a filmnézés során, ahelyett, hogy világosan lokalizálná a mozgóképi élmény helyszíneit a »vásznon« és »vásznon kívül« kategóriái által.” ${ }^{[29]}$ Az anyagi világ hangokon keresztüli érzékelése a szó szoros értelmében, a hanghullámok közvetítésével a vászon határát fizikailag átlépve találkozik a filmbefogadó testével. Ahogy Merleau-Ponty fogalmaz a szenzuális keresztmodalitásról a hanghatások és az anyagiság vonatkozásában: „Ugyanígy hallom az utcakövek keménységét és egyenetlenségét a kocsi zötyögésében; nem helytelen »puha«, »tompa« és »éles« hangokról beszélnünk." [30]

Éva lakása érzéki atmoszférájának megteremtésében különösen fontos szerepet kapnak a hanghatások. Habár maguk a fém bútorok és az általuk generált hangok a ridegséget erôsítik, a lakás egészének van egy barlangszerú vagy az anyaméhet megidéző hangulata annak köszönhetôen, ahogy a szomszédból átszúrôdô zene tompa hangjai beburkolják (Évának zenehallgatásra csak így van lehetôsége, hiszen elektromos berendezéseket sem használhat), illetve ahogy a légtisztító berendezés sziszegô zajai szinte lélegzô burokká alakítják az Éva számára egyedül biztonságos helyet.

A szinesztéziás érzékelést egyébként a film kifejezetten motívummá is alakítja, amikor Éva az allergiás rosszullétét ahhoz a gyermekkori élményéhez hasonlítja, amikor az óvodában játékhoz használt múanyag karikákat a szeme elé emelte, és mindent a kékes derengésen keresztül érzékelt. Nem tudom, létezik-e még az óvodákban manapság ez a célbadobó játék a belül üreges, színes múanyag karikákkal, de - lévén egyidôs a rendező-forgatókönyvíróval - az ezekhez a karikákhoz kapcsoló szinesztéziás élmény nekem is határozott - tapintás, textúra, szín- és fényérzékletekkel összekapcsolódó - gyerekkori tapasztalatom.

A test, testiség ideája szükségszerúen tematikus szinten is a film fókuszát képezi, hiszen a történet kiinduló bonyodalma éppen az, hogy el kellene dönteni, ami Évával történik, az testének az objektív, anyagi valóságból származó, a materiális ingerekre adott reakciója, vagy pedig pszichoszomatikus eredetú. Az Éden középpontjában tehát bizonyos értelemben pontosan az az ellentmondás feszül, amely a filmbefogadásban a testi fordulatot elôidézte, és a fenomenológiai megközelítést elótérbe tolta: annak igénye, hogy belássuk a testi, valamint a tudati és lélektani 
múködések szigorú elválasztásának lehetetlenségét. Éva karaktere megtestesíti a fenomenológia „megélt test” elgondolását, abban az értelemben, hogy a kortárs világ problémáit - az elmagányosodástól a környezeti katasztrófáig - a testi és lélektani folyamatok szétszálazhatatlan egységeként állítja elénk. András a vizsgálatait követôen a tárgyaláson, ahol nyilatkoznia kellene arról, hogy Éva tünetei pszichológiai vagy külsô behatásra vezethetôk-e vissza, nem tudja egyértelmúen megválaszolni a kérdést.

Ugyanakkor a test és a testi kontaktus fontosságát többször is hangsúlyozza a film. Egy helyen például Éva azt mondja Andrásnak: „az ölelés mindent megoldana, a maga munkájára sem lenne szükség”. Ez az a gyógymód, amelytôl ô maga el van zárva, bezárva a saját testébe. A saját és másik testhez való viszony problematizálására motívumsor épül a filmben. Ide tartozik az a jelenet, melyben a tükör elôtt Éva elôbb saját testét érinti meg erotikusan, majd a tükörképével való csókolózással folytatódik; vagy a maszturbálás jelenete a kádban, mely az elszigeteltség, az önmagába zárt, magányos test kétségbeesett próbálkozása az intimitás, az érzéki tapasztalat szimulálására. Érdekes, hogy ezekkel a kétségbeesett és az erotikát groteszknek és lehetetlennek mutató epizódokkal szemben a reményt és szabadságot két másik, nagyon erôteljesen testileg kódolt epizód képviseli. A Merleau-Ponty-féle „megélt test” ezekben a pillanatokban különös erôvel nyilvánul meg, ami arra utal, Éva talán készen áll, hogy ne csak szimulálja, de valóban újra össze is kapcsolja testét a világgal és másokkal. Az egyik egy apró jelenet, melyet azt követôen látunk, hogy Éva összeszólalkozott Andrással, amiért nem engedi, hogy néha kísérleti jelleggel elhagyhassa a lakást. A vitát követően az éjszakai lakásban látjuk Évát, aki madarak szárnycsapásait utánozza, majd ezt követôen, mintha csak a mozgással megidézte volna a madarakat, seregélycsapat repül a lakás erkélyének korlátjára. Azon a kézenfekvő értelmezésen túl, hogy a madármotívum a szabadság, a kiszabadulás gondolatát idézi meg, Éva hangos lélegzése és mozdulatai dinamikájukkal, életteliségükkel más minôséget képviselnek a saját érzéki teste visszaszerzésében, mint a sokkal inkább kétségbeesettnek tûnô erotikus próbálkozások. A repülés motívumot és a saját test megélésének visszaszerzését aztán Éva táncjelenete teljesíti majd ki késôbb, mely jelenet a testszimbolika tekintetében a film tetôpontjaként is értékelhetô, hiszen a kiszabadulás, a természetes világgal, környezettel való kapcsolatfelvétel a film végén kudarcot vall, vagyis annál szabadabbnak, mint tánc közben, sosem látjuk Évát.

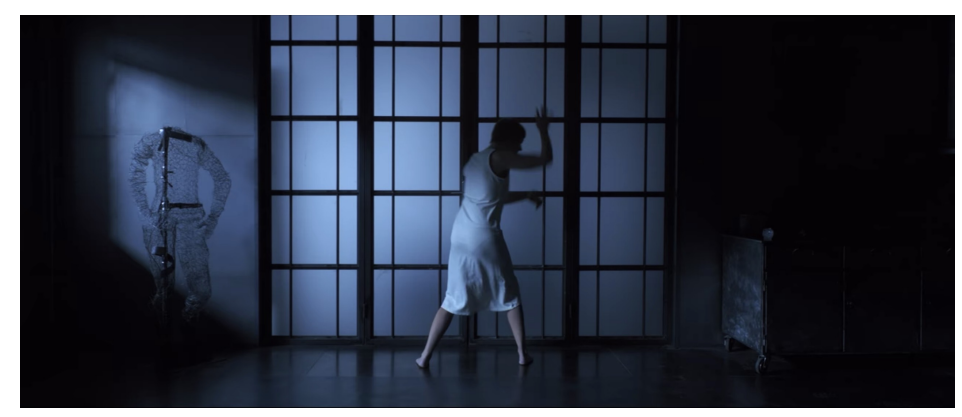

Kocsis Agnes: Éden (2020)

A szkafander a film egyik fontos szimbóluma - ez az, ami elszigeteli, de egyben össze is köti a testet a világgal. Ugyanakkor a film végén további tartalmakkal is feltöltődik. A filmet záró jelenet 
elôtt szereplôinket (Andrást, András kislányát és Évát) látjuk egymás utáni képeken, amint a nagy kiszabadulási kísérlet elốtti éjszakán ágyukban fekszenek. Éva mellett az ágyon fekvô szkafander testesíti meg a hiányzó Másikat, testpótlék, mely mellé le lehet feküdni, amihez hozzá lehet bújni, de amitôl meg is akar szabadulni. A beállítás végén Éva a lepedóvel letakarja a szkafandert, ami így átalakul élettelen holttestté, baljós elôjellé a film végkimenetelét illetôen. A film zárlatában, a szkafandertôl megszabaduló Éva megpróbálja felvenni újra a testi kapcsolatot a külvilággal, sikertelenül. A végsô küzdelemben fontos, hogy Éva meztelen teste nem erotikus, idealizált képként jelenik meg, hanem kiszolgáltatott, esendô voltában nyersen materiális, ziháló és szenvedố test. Az utolsó képsorban a szenvedô nôi test és a Földgolyó metonimikus egymásra írása hangsúlyos szimbólumot teremt. Ez az a kettôsség, a materiális-érzéki, valamint a formálisszimbolikus között feszüló ellentmondás, ami a film egyik alapvetô formai, strukturális jegye.

A feminista fenomenológia a testet öltöttség vizsgálatában kiemelt figyelmet szentel azoknak a módoknak, melyek a nôk és férfiak mozgását, a térhez való kapcsolatát jellemzik, úgy mint a testtartás vagy a mozgékonyság. S mivel a feminista fenomenológiát a vásznon látott nôi karakterek mint testet öltött szubjektumok tapasztalatai és vágyai érdeklik, ezért az efféle elemzéseknek jó alapja lehet Sobchack „sûrú leírás” módszere. A (női) karakterek testének és mozgásának ilyen leírása képezheti az alapját a szubjektivitás fenomenológiai alapú elemzésének. [ $31^{]}$

A két fôhoós térhez való viszonya nagyon beszédes különbségeket mutat az Édenben. Éva és András elsô közös jelenetében, amikor leülnek beszélgetni, a nô mozgása nagyon takarékos, szinte összehúzódik, megpróbál minél kisebb teret betölteni a testével, pedig ő az, aki otthon van. A férfi viszont azonnal lendületesen átrendezi a teret, nagy mozdulatokkal áthelyezi a széket, hogy saját feladatának és céljának megfelelô legyen az elrendezés. András térbeli mozgása, a teret uraló viselkedése különösen szembetúnô a nô térhez való viszonyával összevetve. Andrást késôbb is látjuk ilyen módon átrendezni a teret, miközben Éva testvére (Gyuri) kívül az ablakot takarítja. Éva meg is jegyzi, hogy Gyurinak némi akrobatikus teljesítményre is szüksége van az ablaktakarításhoz, hiszen a szomszédból kell átmásznia az erkélyre, mivel az ajtót-ablakot Éva lakásában nem lehet kinyitni. A mozgás, a mobilitás, a cselekvés lehetôsége mind a férfiak privilégiuma Éva világában.

A film egyik központi mozgatórugójává késôbb aztán éppen az válik, hogy amikor a bírósági ügy érdekében végzett pszichológiai vizsgálatból Éva érdekében végzett terápia lesz, egyre inkább felerôsödik a kitörés vágya Évában. ${ }^{[32]}$ A szöveg elején említett koncertjelenet után, az addig a testi kontaktust lényegében kerülô szereplôk között megtörténik az elsô, bátortalan és szinte kelletlen ölelés, mely alkalommal Éva ismét azt kéri, hogy hadd próbáljon meg védôfelszerelés nélkül kimenni a szabadba. A fontos momentumok a két hôs kapcsolatának alakulásában mindig összekapcsolódnak a ki- vagy kijjebb jutás motívumával, azzal hogy Éva újra megpróbálja felvenni a kapcsolatot a világgal, megpróbálja testét újra korlátozás nélkül „megélt testként” birtokolni.

Éva tragédiájának térbeli kidolgozása több szinten is zajlik a filmben. Az alaphelyzetet a sajátosan 
steril és hermetikusan lezárt lakásba való bezártság jelenti. Ehhez jön hozzá a film

szisztematikusan felépített akváriumszimbolikája. A film legelsố képein egyból a laboratóriumban épített üvegkalitkában látjuk Évát. Az ezt követô (már említett) hazafelé vezetô autózás jelenetében Éva kettôs üvegfelület mögé zártsága is e motívumsorba illik. Rendszeresen látjuk Évát kívülrôl, a lakása erkélyéról nézve az ablaküvegek mögött, mint egy akváriumba zárt lényt. A motívumot tovább építi a lakásban lévô akvárium, melyben Éva életteret teremt a teknôsöknek. Késôbb az ûrállomásra emlékeztetô, kivilágított kilátóhely kupolája és a sivatagi kísérleti telep üvegigluja is valamiféle akváriumot idéznek. Szinte szükségszerúnek látszik, hogy ezután a tropikárium akváriumalagútjában is játszódik egy jelenet, melyben a szkafanderes Éva alakját körülvevő akvárium az óceánok és az ûr végtelenségét is megidézi, ugyanakkor bezártságát még inkább kihangsúlyozza. Az akváriumszimbolika lesz az Évát sokszoros, egyszerre áttetszô mégis áthatolhatatlan burokba záró klausztrofób helyzet térbeli trópusa. A szimbólumsor látványos lezárása a film végi, szabadba való kirándulásra történő felkészülés jelenete, melyben Évát újra a laboratóriumi üvegkalitkában látjuk - a körben a falra vetített természeti képek Évát mint egy virtuális növényekkel betelepített akvárium lakóját mutatják.

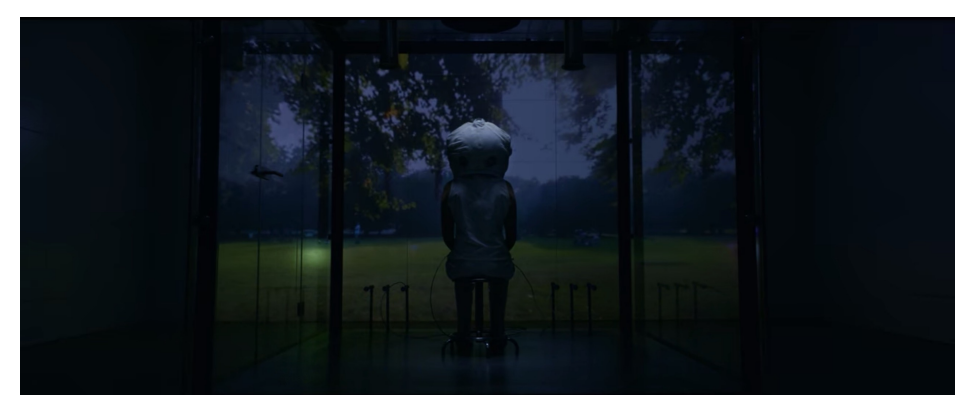

Kocsis Agnes: Éden (2020)

A térbeli korlátozottságnak mindezek a kifejeződései alapvetôen járulnak hozzá ahhoz, hogy Éva világát érzékletes térbeli konstrukcióként teremtsék meg a nézói érzékelés számára. A térbeliség koncepciója pedig a testiesült érzékelés fenomenológiai koncepciójának meghatározó összetevôje. Ahogy Sobchack fogalmaz: „Testiesült filmélményünk eszerint olyan látás-, hallás-, tapintás-, mozgás-, íz- és szaglásélményekból áll, amelyekben a szó szerinti és a képletes értelem (jelentés) néha oszcillál, vagy borzongató hiány formájában jelenik meg, de legtöbbször az érzékek közös bár meglehetôsen sajátos - jelentésévé áll össze.” [33]

\section{Érzéki képzetek: Portré a lángoló fiatal lányról (Céline Sciamma, 2019)}

Céline Sciamma filmjében a nôi szubjektivitások szövedéke extra réteggel egészül ki, hiszen a mú középpontjában egy leszbikus vonzalom áll. A két fôhős, Marianne és Héloise erôteljes és egymásra irányuló nézése ugyanúgy megelốzi a nézô filmre vetett pillantását, mint a Kate Ince-tôl korábban idézett „elsődleges nézés” filmrendezô és nôi karakterei között. A film másik érdekes vonása, hogy kosztümös film. Imre Anikó egy 2003-as, Enyedi Ildikó Az én XX. századom (1989) címú filmjét tárgyaló cikkében úgy fogalmazott, hogy az ezredforduló környékén az Orlando (Sally 
Potter, 1992) és $A$ zongoralecke (Jane Campion, 1993) nyomdokain kibontakozott a kosztümös drámák globális feminista újrakisajátítása. ${ }^{[34]} \mathrm{E}$ trend kortárs folytatásaként is tekinthetjük Sciamma filmjét.

E kosztümös történet jelentôségteljes tulajdonsága, hogy idôben a 18. század végére, a fotográfia, a mechanikus képrögzítés kora elôttre kalauzol, s ebben a kontextusban kerül a portréfestés, a test reprezentációjának metódusa a film szimbólumrendszerének fókuszába. Héloise a házasság elôl öngyilkosságba menekült testvére helyett kell hogy férjhez menjen. A sosem látott férjjelölt számára a lány anyja portrét rendel, azonban az elsô festô kudarcot vall, mivel Héloise nem hajlandó modellt állni. Így érkezik Marianne a távoli birtokra, hogy ott magát társalkodónônek kiadva alaposan megfigyelje Héloise-t, és titokban megfesse a portréját. A szoros megfigyelés eredménye azonban nemcsak egy festmény lesz, de egy mély és felkavaró szerelem is a két nô között.

A film egyik, a reprezentáció természetére vonatkozó kérdése tehát az, mit is jelent egy modellt lefesteni. Miképpen jön létre a reprezentáció, amikor a lemásolandó, a mimesis tárgya nincs a festô szeme elôtt. Hogyan jön létre a reprezentáció, minek a közvetítésével és milyen kapcsolatban áll az eredeti a másolattal. A titokban, emlékezetből festô portrékészító története ilyen módon magának a vizuális reprezentációnak a természetére, és ezen keresztül a fotográfia és a film ontológiájára kérdez rá. S ennek a kérdésfelvetésnek a centrumában a nôi test és annak ábrázolása áll.

A film egyik tétje a láttatás különböző minőségeinek vizsgálata, a test képzetének és a test érzetének szembeállítása, a kettô között fennálló feszültség. A titokban festô Marianne alapos megfigyeléssel próbálja megteremteni és emlékezetébe vésni Héloise testének képzetét, míg a film (írásom elején említett) zárójelenetében a filmrendezố a nézô számára is nagyon jelenvaló, életteli test érzéki megjelenítésével próbálja a test érzetét zsigeri módon a befogadó testébe írni. 
A haptikus és érzéki, naturalista ábrázolás tekintetében Sciamma filmje a kosztümös feminista drámák azon vonulatához áll közel, amelyhez $A$ zongoralecke is tartozik. Érdemes azonban megjegyezni, hogy jelen van másféle fogalmazásmód is a kortárs, nôi alkotó által készített kosztümös dráma múfajában. Kiváló példa erre Jessica Hausner Amour Fou (2014) címú filmje,mely ugyancsak a 18. század végére, $A z$ ifjú Werther szenvedései (J.W. Goethe, 1774) nyománromantikus öngyilkossági divatnak hódoló (férfi) poéták világába vezet. Hausner a haptikus ésérzékitôl teljesen eltérô koncepciót alkalmaz a romantika ideáinak és érzelmeinek ábrázolására. Ahalálhóbortos férfiakkal szembeállítja a racionális nôi karaktereket, miközben az érzelmek mintelvont ideák és koncepciók állnak elôttünk, a kompozíciók és a fények használatánakköszönhetôen kimerevített festményekre emlékeztetô, eltávolító jellegú, kifejezetten a haptikusérzékiség ellen dolgozó fogalmazásmóddal. Habár a szenvedély és az érzékenység korszakárólbeszél, ezt az ábrázolás kifejezetten optikai, absztrakt jellegével ellenpontozza. Mintha nemcsak anôknek a halál divatjával szembeni ellenállása és racionalitása lenne itt a (feminista) üzenet tárgya,de az ábrázolás formája is ironikus kommentárja a kor ideáinak.

Sciamma filmjében viszont erôteljes a testi megszólítottság, és a haptikus elemek is fontos szerephez jutnak. Már a film legelején nagyon határozott stilisztikai gesztusok irányítják rá a figyelmünket a vizuális ábrázolásnak a film szempontjából jelentôségteljes elemeire. A fốcím alatt a papíron sikló kréta hangja, a rajzoló kezek mozdulata azonnal nagyon tapintható világba vezeti a nézốt. A rajzolók szubjektívjébool látjuk a papírt, az elsố snittekben azonnal - mint a következô beállításokból kiderül - nôi festốtanoncok testébe pozicionálja nézôjét a film. Innen nôi arcokra váltunk - intenzív tekintetek sorjáznak, melyek a vásznat figyelik. Közben egy nói hangot hallunk, mely instrukciókat ad, irányítja a nôi tekinteteket. „Alaposan nézz meg engem” - mondja a hang, majd megjelenik a hanghoz tartozó Marianne a képen, modellként, üló pozitúrában. Kéri a rajzolókat, hogy a keze elhelyezkedését figyeljék. A testére koncentrálunk mi is a tanoncokkal együtt, a saját teste pozícióját elemzô nôre. Irányítja szemünk és testünk figyelmét, így azonnal érezzük a feszültséget, amikor az a bizonyos kéz - melyet pontosan úgy helyezett el az ölében, ahogyan azt Héloise portréján megfestette - hirtelen ökölbe szorul. Ez a kis epizód úgy múködik a nézô számára, mint egy vizuális segédeszközökkel irányított relaxációs gyakorlat. Az instruktor bizonyos testrészekre koncentrálja a figyelmet, így annak a testrésznek a mozdulata hangsúlyossá, a vizuális észlelés közvetítésével testi ingerré is alakul a nézôben. S ekkor a festô tanoncok mind a feszültség tárgya felé fordulnak: ez egy festmény „egy lángoló fiatal lányról”, mely csak némi késleltetés után, a nôi tekintetek bonyolult szövedékét kihasználó snittváltásokat követôen tárul fel elôttünk is.

Ez a jelenet sûrítve tartalmazza a film egyik fô konfliktusát, az érzéki, megélt test, valamint a szigorúan szabályozott nézések eltávolító rendjének feszültségét. Azonban azt, hogy a kettô nem választható el, és éppen az ôket összekötô dinamika a lényeg, az is mutatja, hogy a filmben a festéshez, festményekhez gyakran kapcsolódnak haptikus minôségek. Például abban a jelenetben, amikor az elôző, sikertelen portréfestő próbálkozását, egy Héloise-t arc nélkül ábrázoló festményt Marianne a sötét szobában elôbb egy gyertya meleg fényével szinte végigtapogat, majd lángra 
A történet első felének fókuszában ugyanakkor még az intenzív nézés áll, az, ahogy Marianne próbálja alaposan megfigyelni Héloise-t a festmény érdekében.

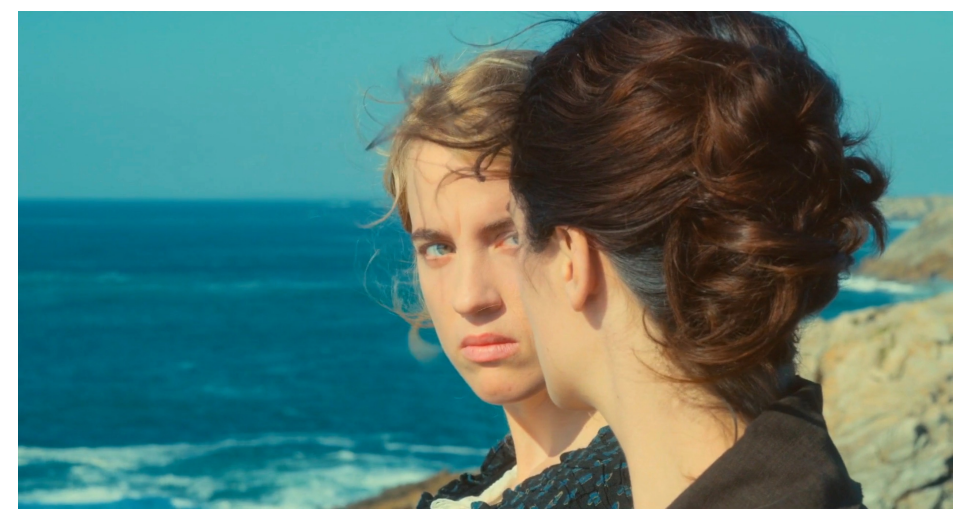

Céline Sciamma: Portré a lángoló fiatal lányról (2019)

A megfigyelés tanulságait, a megfestés technikáját belsô monológban is rögzíti, [35] az arc és a fej megfestésének mozzanatairól, a fény és az árnyalatok szerepérôl beszél - Héloise testének, a felkeltett érzékleteknek az alapos elemzése ez. A jelenetet, melyben Marianne emlékezetból próbálja elkezdeni a festményt, ismét az érdes papír, a rajta sikló kréta hangja, a megfigyelés által belsővé tett képek mozdulatokká alakítása teszi erôteljesen haptikus és testet öltött élménnyé.

Ennek az elsô résznek a „nézésközpontúságát” ugyanakkor olyan epizódok erôsítik, mint a tengeri séta közben hirtelen hátraforduló Héloise, aki kifejezetten ránk néz (belenéz a kamerába). Vagy a tekintetek uralta szakasz lezárását indító jelenet, melyben Marianne bevallja, hogy festô, amire Héloise azzal reagál, hogy „ez megmagyarázza, miért néztél úgy”. Ezt követôen láthatjuk az emlékezetbôl festett portrét. A portrét vizsgáló Marianne és Héloise párbeszéde egyfajta fenomenológiai traktátusként is érthetô. A kérdésre, hogy Marianne tényleg ilyennek látja-e Héloise-t, a festô azt válaszolja, ez nemcsak az ô látása, hanem szabályok, konvenciók és ideák határozzák meg a képet. Héloise ugyanakkor az életet, a jelenlétet hiányolja belôle. Marianne szerint a jelenlét tünékeny pillanatokból áll, melyek talán híján vannak az igazságnak. „Nem minden tünékeny, vannak mély érzések" - válaszolja Héloise. Héloise mintha a fenomenológiai „megéltséget” hiányolná Marianne absztrakt és konvenciókon alapuló reprezentációelképzeléséból. Ennek az elsô résznek a lezárása, amikor elkezdődik a valódi modell alapján történô festés, vagyis amikor Marianne elkezd az életteli test, a jelenlét alapján dolgozni. Miután hosszan és akkurátusan (feltehetôen a konvenciók szerint) beállította a pózt, Marianne utasítására („Nézz rám!”) Héloise egy valóban mélyreható pillantást vet rá. A nézés erejétôl Marianne zavarba jön, talán a nézó is. E nézés ereje hirtelen megélt testté változtatja Héloise-t. Az elvont, képzeletben és emlékezetben megteremtett test és reprezentáció átadja a helyét a megélt testtel való kapcsolaton alapuló képalkotásnak, mint ahogy a két nô közötti viszonyban is átlépünk az ideák és a látvány terepérôl az érzéki, testi kapcsolat felé. A test, a reprezentáció és az erotika összekapcsolásának csúcsjelenetében - hogy elválásuk után Héloise-nak is legyen képe szerelmérôl - a Héloise 


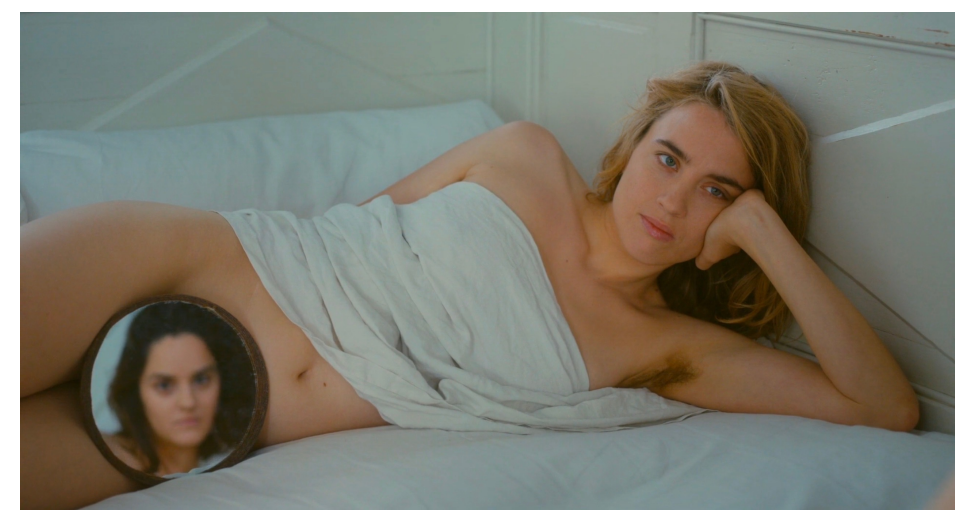

Céline Sciamma: Portré a lángoló fiatal lányról (2019)

Ezúttal is érdekes megfigyelnünk a feminista fenomenológia által felvetett szempontot: a (nôi) test és mozgásának viszonyát a térhez. Ebben a filmben, egy-két rövid jelenetet leszámítva, lényegében nincs férfi szereplô, így összehasonlításra nincs lehetôség. A nôi figurák kapcsán azonban annál határozottabban használja a rendezô a mozgásalapú értelemképzést. Egyrészt a történet elején Marianne csónakos érkezése az események helyszínére nagyon dinamikus és érzékileg telített jelenetben zajlik, mely némileg megidézi $A$ zongoralecke hasonló kezdését. Hôsnônk különlegességére rögtön felfigyelünk, amikor a csónakban üló férfiakkal ellentétben ô az egyetlen, aki a háborgó tengeren vízbeesố ládája után ugrik. Majd pedig látjuk, ahogy nagy csomagjaival egyedül mászik fel a partról a meredek hegyoldalon. Aktív, cselekvô, határozott és rettenthetetlen figuraként exponálja ôt a film ezekben a jelenetekben.

Héloise jellemzésében is fontos szerepet kap a mozgás, a teste feletti kontroll visszaszerzése. Elsô közös tengerparti sétájukkor Héloise hirtelen rohanni kezd a sziklafal pereme felé. Marianne, aki azt hiszi, talán testvéréhez hasonlóan ô is öngyilkosságra készül, rémülten fut utána. A meredély szélén Héloise így szól: „Már régóta álmodtam errôl.” „A halálról?” - kérdezi Marianne. „Nem, a futásról."

Amikor Marianne késôbb egy tengerparti sétájuk során leleplezi küldetését, Héloise reakciója ekkor is jellegzetesen testi, mozgáshoz kapcsolódó: bemegy a tengerbe, hogy kipróbálja, tud-e úszni. A nôi sors szabta korlátok okozta frusztrációból sarjadó lázadás pillanatai ezek, amikor felszabadult, dinamikus mozgásban látjuk Héloise-t. A futás még további jelentéssel is feltöltôdik a filmben: a cselédlány nem kívánt terhességétôl különféle megerôltetố testgyakorlatokkal próbál megszabadulni, például végkimerülésig tartó futással. Ezek a dinamikus mozgások, amikor a nôi testek határozottan birtokba veszik a teret, mind az önállóság, a szabadság, a korlátoktól való megszabadulás kifejezôivé válnak.

Ugyanakkor a film központi motívumául szolgáló festészet is sajátosan illeszkedik a fenomenológiai gondolatmenetbe. Merleau-Ponty utolsó, befejezetlenül maradt múvében, A látható és a láthatatlanban ${ }^{[36]}$ az érzékelésrốl a látvány és a festészet vonatkozásában beszél. Ahogy Ullmann Tamás fogalmaz Merleau-Ponty észleléselméletérôl szóló tanulmányában: 
„Testünk, a világ húsába illeszkedô húsunk észleleti módon lép kapcsolatra a számára feltárulkozó világgal. Ennek az észlelésnek immár nem a megismerố mozgás az alappéldája, amiben aktivitás áll szemben passzivitással, hanem sokkal inkább a múvészi alkotó tevékenység, amelyben aktivitás és passzivitás kibogozhatatlanul egybefonódik. Nem véletlen, hogy a késôi Merleau-Ponty számára a festészet lett az a paradigmatikus tevékenység, amivel a leggyakrabban jellemezte az észlelés folyamatát. A festészet öntudatlanul múveli azt, ami a fenomenológiában tudatossá válik: felfüggeszti a mindennapok tapasztalatát, és visszatér az eredeti látáshoz. A festészet egyfajta »testi reflexió«, amely nem gondolati úton, hanem a szemlélet alapzatához való visszatéréssel mutatja meg nekünk a világ elfelejtett dimenzióit." [37]

Sciamma filmje a fentebb bemutatott példák szerint számos módon kapcsolódik a festészet mint testi reflexió gondolatához. Ugyanakkor a festô karakterén és a modelljére irányuló nézésén keresztül a film a nôi interszubjektivitást erôteljesen írja bele a film diegetikus szövetébe. Az efféle interszubjektivitás jelentôségére Merleau-Ponty is rámutat a film és pszichológia kapcsán írt szövegében. Szerinte az olyan érzésekról, mint a szeretet vagy gyúlölet pusztán introspekcióval, befelé nézve nem tudhatunk meg semmit. A saját érzéseinket viselkedésként, a másokhoz és a világhoz való viszonyunk megváltozásaként kell tanulmányozni. Akkor érthetô meg belólük valami, ha sikerül úgy gondolni rájuk, mint egy másik ember viselkedésére, melynek csupán tanúi vagyunk. ${ }^{[38]} \mathrm{A}$ két főhôsnő viszonyában fontos az ilyesféle, a megfigyelô és a megfigyelt között megnyilvánuló dinamika, aminek szép példája a jelenet, melyben Marianne a modellje gesztusai mögött rejlő érzelmeket elemzi, mire Héloise is elmond egy ugyanilyen elemzést a festô mozdulatairól, hiszen ố is ugyanúgy megfigyeli a másikat festés közben. A megfigyelói attitűd természetesen a nézô és a film viszonyában is jelen van, sôt Merleau-Ponty szerint éppen ebbôl adódik a film fenomenológiai eloonye: „[A]z érzékelés segítségével érthetjük meg a film jelentését; a film nem gondolkodik, érzékelődik. Ez hát az oka annak, hogy annyira megragadó a film emberábrázolása: a filmból nem ismerhetjük meg - mint a regényekből - az emberek gondolatait, de láthatjuk magatartásukat, viselkedésüket.” [39]

Mivel ebben a filmben lényegében csak női szereplók vannak, kifejezetten alkalmas arra, hogy odafigyeljünk Kate Ince javaslatára, miszerint „különösen fontos a női szubjektumok egymás közötti viszonyának fókuszba állítása a filmek narratívájában és a nézés szituációjában, különös figyelmet fordítva a két nôi alany közti dinamikaként felfogott nôi interszubjektivitásra”. [40] Ennek az interszubjektivitásnak a nézô-nézett, festô-modell viszonyban való megjelenésére fentebb láttunk már példákat. Még egy jellegzetes motívum kívánkozik ide ennek a kérdésnek a megvilágításához: a felcserélések, helycserék és behelyettesítések motívumsora a két fôszereplô, valamint a cselédlány viszonylatában (akivel közösséget vállalnak, amikor segítik megszabadulni a nem kívánt terhességtől).

A film első felében, amikor a festés még titokban zajlik, Héloise testének behelyettesítése indítja a motívumsort. A modell nélküli festés elômozdítására Marianne elôbb maga öltözik be a ruhába, melyet a festményen Héloise kellene viseljen, s a tükörben szemléli magát, hogy az emlékezetből már megfestett archoz kiegészítésként saját testét használja modellnek. Késôbb hosszan a ruha 
ujjának akkurátus megfestését figyeljük, hogy egy idő után kiderüljön, a cselédlány az, aki a modell helyén ül a ruhában. S ide kapcsolódik a fentebb már említett jelenet, melyben a festô és modellje az egymás gesztusai mögött rejló érzéseket sorolják, amiből kölcsönös megfigyelôi pozíciójuk válik nyilvánvalóvá, vagy ahogy Héloise fogalmaz: „Mindketten ugyanott vagyunk, teljesen azonos a helyzetünk, amikor te engem nézel, én téged nézlek."

A film zárlatában sưrítetten is megismétlődik az ív, mely a film egészében jelen volt: a testetlen képzetektől, a festett reprezentációkon át, az érzéki, szenzuális testig. A film során többször láttuk Marianne számára kísérteties látomásként, fehér ruhában megjelenni Héloise-t. Végsố búcsújukkor a festmény elkészülte után ebben a fehér, esküvői ruhában látjuk Héloise-t, mint egy immár megtestesült látomást. Következô találkozásuk egy festmény által zajlik - Marianne egy kiállításon látja Héloise portréját. S végül, a szövegem elején leírt záró snittben, Héloise hangsúlyozottan életteli teste materiális, érzô teljességében jelenik meg elôttünk, felülírva minden testetlen tüneményt és festett reprezentációt. Ebben a hosszú beállításban a film mintha valóban kísérletet tenne arra, hogy saját érzô testünkben éljük meg Héloise és az ôt velünk együtt figyelô Marianne fájdalmát. Hogy miféle lehetôségünk van erre a testetlen fénynyalábok rajzolta mozgókép segítségével, arról írja Sobchack: a film iránti érdeklődésem „nem csupán a tudatos figyelemben nyilvánul meg, hanem testem feszültségében és állapotában is”. Amikor nem tudom szó szerint megérinteni, ami felkeltette az érdeklődésemet, a megragadás célpontját egy hozzáférhetố tárgyra helyezem át. Ez a „hozzáférhetô érzéki tárgy, nem más, mint a saját, szubjektív, megélt testem. (...) reflektív gondolatok közremúködése nélkül - reflexszerúen, karnálisan fordulok saját karnális létem felé, hogy (...) érzékeljem saját szenzualitásomat.” [41]

\section{Jegyzetek}

1. Merleau-Ponty, Maurice: A film és a modern pszichológia. Ford. Morvay Zsuzsa. Metropolis, 2004/3. 16.

2. Sobchack, Vivian: What My Fingers Knew: The Cinesthetic Subject, or Vision in the Flesh. In Sobchack: Carnal Thoughts: Embodiment and Moving Image Culture. Berkeley-Los Angeles-London, University of California Press, 2004. 53-84. [Magyarul: Amit az ujjaim tudnak: A cinesztéziai szubjektum, avagy a testi tekintet. Ford. Liszka Tamás. Metropolis, 2004/3. 18-39.]

3. Sobchack: Amit az ujjaim tudnak. 24.

4. A magyar fordításban a „sense-making” megfelelőjeként az „észlelt” (vagyis „érzékletet létrehozó”) szerepel, itt most a kifejezés másik olvasási lehetôségét használom: a „making sense” („értelmes”) irányából olvasva „értelemképzônek” fordítom

5. Sobchack, Vivian: The Address of the Eye: A Phenomenology of Film Experience. Princeton, Princeton University Press, 1992. xv.

6. Sobchack: Amit az ujjaim tudnak. 25.

7. Ullmann Tamás: A francia fenomenológia kialakulása és Merleau-Ponty észleléselmélete. Metropolis, 2004/3. 68-78. 74.

8. Sobchack: The Address of the Eye. 8. [Itt és a továbbiakban, ha másként nem jelzem, az idézetek a saját fordításaim. VT]

9. Sobchack: Carnal Thoughts. 179.

10. Sobchack: The Address of the Eye. p. xvii. Az idézett részben szereplö „enworlded lived body” kifejezés 
magyarítását Sobchack: Amit az ujjaim tudnak címú szövegének megjelent magyar fordításából veszem át.

11. Andrew, Dudley: The Neglected Tradition of Phenomenology in Film Theory. Wide Angle, 2.2 (1978), 4449. [Magyarul: Andrew: A fenomenológia hagyománya a filmelméletben. Ford. Bocsor Péter. Metropolis, 2004/3. 62-67.]

12. Andrew: A fenomenológia hagyománya a filmelméletben. 63.

13. Sobchack szóalkotása a „cinema” és a „szinesztézia” kifejezésekból.

14. Sobchack: Amit az ujjaim tudnak. 39.

15. Ince, Kate: The Body and the Screen: Female Subjectivities in Contemporary Women's Cinema. New York, Bloomsbury, 2017. 26.

16. Studlar, Gaylyn: Reconciling Feminism and Phenomenology: Notes on Problems and Possibilities, Texts and Contexts. Quarterly Review of Film and Video, 12.3 (1990), 69-78.

17. Sobchack: The Address of the Eye.

18. Ince: The Body and the Screen. 27.

19. Sobchack: The Address of the Eye. xv.

20. Penley, Constance: The Future of an Illusion: Film, Feminism, and Psychoanalysis. London, Routledge, 1989.

21. Ince: The Body and the Screen. 31. Ugyanakkor azt, hogy az ilyen törekvések ma már nem példa nélküliek, jól jelzi Árva Márton jelen összeállításban megjelenő szövege is, amely egy politikai indíttatású, jellegében kultúratudományi diskurzust, a dekoloniális megközelítést kapcsolja össze a fenomenológiával. Lásd: Árva Márton: Perspektivaváltások. A filmfenomenológia és a dekoloniális gondolkodás lehetséges párbeszédérôl. Apertúra, 2020. tél. URL:

22. Del Rio, Elena: Rethinking Feminist Film Theory: Counter-narcissistic Performance in Sally Potter's Thriller. Quarterly Review of Film and Video, 2003/1. 11-24. 11.

23. Ince: The Body and the Screen. 38.

24. Grant, Catherine: Secret Agents: Feminist Theories of Women's Film Authorship. Feminist Theory, 2.1 (2001): 113-130. 116.

25. Ince: The Body and the Screen. 42.

26. Ince: The Body and the Screen. 26.

27. Sobchack: The Address of the Eye. xv.

28. Sobchack: Amit az ujjaim tudnak. 22., 23.

29. Sobchack: Amit az ujjaim tudnak. 28., 30.

30. Merleau-Ponty, Maurice: Phenomenology of Perception. Ford. Colin Smith. London, Routledge \& Kegan Paul, 1962. 230., idézi: Sobchack: Amit az ujjaim tudnak. 31.

31. Ince: The Body and the Screen. 41-42.

32. „Menjünk ki, legyen kinn a terápia!” - követeli a film 59. percében Éva Andrástól.

33. Sobchack: Amit az ujjaim tudnak. 33.

34. Imre, Aniko: Twin Pleasures of Feminism: Orlando Meets My Twentieth Century. Camera Obscura, 18.54 (2003), 176-211. 188.

35. Portré a lángoló fiatal lányról: 21 perc.

36. Merleau-Ponty, Maurice: Le visible et l'invisible. Paris, Gallimard, 1964. [Magyarul: A látható és a láthatatlan. Budapest, L’Harmattan-SZTE Filozófia Tanszék, 2006.]

37. Ullmann Tamás: A francia fenomenológia kialakulása és Merleau-Ponty észleléselmélete. Metropolis, 2004/3. 68-78. 78 . 
38. Merleau-Ponty: A film és a modern pszichológia.12-13.

39. Merleau-Ponty: A film és a modern pszichológia. 16.

40. Ince: The Body and the Screen. 42.

41. Sobchack: Amit az ujjaim tudnak. 34 .

\section{Irodalomjegyzék}

- Andrew, Dudley: A fenomenológia hagyománya a filmelméletben. Ford. Bocsor Péter. Metropolis, 2004/3. 62-67.

- Del Rio, Elena: Rethinking Feminist Film Theory: Counter-narcissistic Performance in Sally Potter's Thriller. Quarterly Review of Film and Video, 2003/1. 11-24. https://doi.org/10.1080/10509200490262424

- Grant, Catherine: Secret Agents: Feminist Theories of Women's Film Authorship. Feminist Theory, 2.1 (2001) 113-130. https://doi.org/10.1177/14647000122229325

- Imre, Anikó: Twin Pleasures of Feminism: Orlando Meets My Twentieth Century. Camera Obscura , 18.54 (2003): 176-211. https://doi.org/10.1215/02705346-18-3_54-177

- Ince, Kate: The Body and the Screen: Female Subjectivities in Contemporary Women's Cinema. New York, Bloomsbury, 2017. https://doi.org/10.5040/9781501396519

- Merleau-Ponty, Maurice: A film és a modern pszichológia. Ford. Morvay Zsuzsa. Metropolis, 2004/3. 10-16.

- Merleau-Ponty, Maurice: Le visible et l'invisible. Paris, Gallimard, 1964. [Magyarul: A látható és a láthatatlan. Budapest, L'Harmattan-SZTE Filozófia Tanszék, 2006.]

- Sobchack, Vivian: Carnal Thoughts: Embodiment and Moving Image Culture. Berkeley-Los Angeles-London, University of California Press, 2004. https://doi.org/10.1525/9780520937826

- Sobchack, Vivian: The Address of the Eye: A Phenomenology of Film Experience. Princeton, Princeton University Press, 1992. https://doi.org/10.1515/9780691213279

- Sobchack, Vivian: What My Fingers Knew: The Cinesthetic Subject, or Vision in the Flesh. In Sobchack: Carnal Thoughts: Embodiment and Moving Image Culture. Berkeley-Los Angeles-London, University of California Press, 2004. 53-84. [Magyarul: Amit az ujjaim tudnak: A cinesztéziai szubjektum, avagy a testi tekintet. Ford. Liszka Tamás. Metropolis, 2004/3. 18-39.] https://doi.org/10.1525/9780520937826

- Studlar, Gaylyn: Reconciling Feminism and Phenomenology: Notes on Problems and Possibilities, Texts and Contexts. Quarterly Review of Film and Video, 12.3 (1990), 69-78. https://doi.org/10.1080/10509209009361353

- Ullmann Tamás: A francia fenomenológia kialakulása és Merleau-Ponty észleléselmélete. Metropolis, 2004/3. 68-78. 


\section{Filmográfia}

- A zongoralecke (The Piano. Jane Campion, 1993)

- Amour Fou (Jessica Hausner, 2014)

- Az én XX. századom (Enyedi Ildikó, 1989)

- Éden (Kocsis Ágnes, 2020)

- Orlando (Sally Potter, 1992)

- Portré a lángoló fiatal lányról (Portrait de la jeune fille en feu. Céline Sciamma, 2019)

- Sztalker (Stalker. Andrej Tarkovszkij, 1979) 
(C) Apertúra, 2021. tél | www.apertura.hu

webcím: https://www.apertura.hu/2021/tel/vincze-noi-erzekek-rendezonok-noalakjainak-

fenomenologiai-olvasata/

https://doi.org/10.31176/apertura.2021.16.2.9

(Q) opertúro 